\title{
Storms influence cattle to graze larkspur: An observation
}

\author{
MICHAEL H. RALPHS, DON T. JENSEN, JAMES A. PFISTER DARWIN B. NIELSEN, AND LYNN F.
} JAMES

\begin{abstract}
Authors are range scientist, USDA/ARS Poisonous Plant Research Lab., 1150 E 1400 N, Logan UT, 84321; Utah State climatologist, Plant Soils and Biometeorology Dept. Utah State Univ., Logan UT 84322; range scientist, USDA/ARS Poisonous Plant Research Lab., professor, Economics Dept. Utah State Univ; and research leader, USDA/ARS Poisonous Plant Research Lab.
\end{abstract}

\begin{abstract}
Livestock producers report cattle deaths from larkspur (Delphinium spp.) poisoning increase during stormy periods. In controlled grazing studies, we observed cattle increase larkspur consumption during stormy weather. Periods of "gluttonous" larkspur consumption generally coincided with storms during a 1990 grazing study. Cattle consumed larkspur almost exclusively for 20-30 min periods during storms, as opposed to intermittent grazing of larkspur flowers, pods, and leaves. In 1991, weather parameters were measured and correlated with larkspur consumption. Larkspur consumption was negatively correlated with decreasing temperature and barometric pressure $(r=-0.45$ and -0.60 respectively); and positively correlated with increasing relative humidity, leaf wetness, and precipitation $(r=0.45,0.74$, and 0.27 , respectively). Understanding consumption patterns of cattle grazing larkspur will aid in developing management strategies to reduce cattle deaths.
\end{abstract}

Key Words: Weather, bioclimatic factors, cattle grazing, poisonous plants, tall larkspur (Delphinium barbeyi L. Huth).

There is a widespread belief among stockmen that cattle are poisoned by larkspur (Delphinium spp.) after rain or snow showers during late spring and summer. Several theories have been offered to explain this phenomena. Wilcox (1899), suggested that cattle pull up larkspur by the root when soils are wet and are poisoned by eating the root. This speculation lead to a widespread misconception that only larkspur roots poisoned livestock. Marsh and Clawson (1916) discounted this idea because larkspur stems readily break off at the crown, and it is highly unlikely that the deep tap root can be pulled up. They noted that cattle gather under trees for protection during storms, where larkspur is abundant, and perhaps eat more of it. Nielsen (personal observation) observed cattle running for shelter of conifer groves as high intensity thunderstorms descended. He speculated that if the cows were eating near lethal doses of larkspur, the extra physical exertion and stress on the respiratory system and skeletal muscle was enough to kill them.

\footnotetext{
The authors wish to express thanks to OmniData International for use of weather monitoring. and assistance in calibrating the equipment.

Manuscript accepted 30 Dec. 1993.
}

Cronin and Nielsen (1979) coined the term "gluttonous consumption" to describe the rapid and exclusive consumption of entire larkspur plants, as opposed to routine selection of flowers, pods, and leaves. We observed periods of gluttonous consumption coincided with cold rain showers in controlled grazing studies. Pfister et al. (1988a) reported cattle increased consumption of tall larkspur ( $D$. barbeyi L. Huth) after the first 2 rain showers following a prolonged dry period. Pfister et al. (1988b) and Lane et al. (1990) also reported unusual feeding behavior for 15-20 min periods following cold rain showers. Cattle were playful, throwing their tails in the air, running from 1 larkspur plant to another, rapidly consuming larkspur, and occasionally eating the plants down to the ground. Ralphs and Olsen (1992a) reported that waxy larkspur (D. glaucescens Wats.) consumption peaked following rain and snow storms in Montana.

The objective of this study was to identify and describe periods of gluttonous larkspur consumption and correlate larkspur consumption to various weather components associated with storms.

\section{Methods}

\section{Grazing Trial, 1990}

Ralphs and Olsen (1992b) reported tall larkspur in cattle diets peaked during summer thunderstorms on the Wasatch Plateau in central Utah in 1990. A retrospective examination was made of these data to describe periods of gluttonous consumption and their relation to storms.

The study was conducted on the 6-Mile Forest Service Allotment on the Wasatch Plateau, $24 \mathrm{~km}$ east of Manti, Ut. The site was in the subalpine vegetation zone (3,050 m elevation). Groves of Engleman spruce (Picea engelmanii Parry ex Engelm.) dotted the area, and current (Ribes montigenum McClatchie) thickets and elderberry (Sambucus racemosa L.) patches were abundant. Tall larkspur dominated the tall forb plant community on snowdrift sites. Mountain brome (Bromus carinatus Hook. \& Arn.), slender wheatgrass (Agropyron trachycaulum (Link) Malte), and daisy (Erigeron spp.) dominated the open areas.

Three, 1.5-ha pastures were fenced with temporary electric fence. Twelve 1-year-old Hereford heifers $(230 \pm 26 \mathrm{~kg})$ were initially divided into 3 groups and grazed separately for 6 days, then the partition fences were removed and they grazed together for 8 days. The study was designed to determine if cattle averted to larkspur would 
retain the aversion while grazing separately and then when grazing with control heifers that were eating larkspur. Cattle were observed each day during the major morning, midday and evening grazing periods and diets were quantified by scan sample (Lehner 1987). A scan of all animals was made at 2-min intervals and the plant each animal was eating was recorded. This procedure estimated the proportion of time each animal spent grazing larkspur.

Mean daily larkspur consumption was reported by Ralphs and Olsen (1992b). However, events of "gluttonous consumption" were not described in that paper. We define gluttonous consumption as short periods (20-30 min) of almost exclusive larkspur consumption involving all animals compared to incidental or infrequent bites of larkspur intermingled with other forage.

The intermittent recording of 2 min scan samples did not accurately describe the dynamic character of these continuous events. Therefore, we have supplemented the data with a narrative of the events as we observed the cattle.

\section{Grazing Trial, 1991}

A grazing study was conducted in 1991 to determine the influence of weather components on larkspur consumption. The study was conducted at the same location using the same protocol as the 1990 study. However, pasture size was increased to 5 ha and four 2-yearold Hereford X Angus heifers grazed the area from 16 August to 12 September. Larkspur was in the flower stage at the beginning of the study, and matured to the pod stage during the study.

A weather station ${ }^{1}$ was assembled on site to record: ambient air temperature, relative humidity, precipitation $(20 \mathrm{~min}, 2$ hour, and daily accumulation), leaf wetness (percent of time leaves were wet from rain or dew), wind speed and direction, wind gust, barometric pressure and 3-hour change in pressure, and solar radiation. The data were recorded at $10 \mathrm{~min}$ intervals. The mean values of the weather components were calculated for the respective grazing periods and used in the analysis. There were 74 grazing periods during the 28-day study. However, the power supply to the weather station failed from 24 to 26 August, and from 29 August to 5 September. A backup system comprised of a wind-up mini-barograph, hygrothermograph and a standard rain bucket measured barometric pressure, relative humidity, temperature, and precipitation. These data replaced the missing data from the weather station for these weather components on these dates.

The proportion of time cattle spent grazing larkspur was correlated with the mean value of each weather component during the corresponding grazing period using the Pearson product-moment correlation (SAS 1985). Correlations were also calculated between the mean daily larkspur consumption and the average daytime values of the weather components.

\section{Results}

\section{Grazing Trial}

Mean daily larkspur consumption during the 1990 grazing study ranged between 2 and 17\% (Fig 1). However, 4 periods of gluttonous consumption occurred during stormy periods. These events generally lasted only 20 to $30 \mathrm{~min}$. The first event (24 August) was associated with a rapidly moving cold front. Although no rain fell, there was a distinct drop in temperature, high gusty winds, and a dense cloud cover. At this time, the heifers were divided into 3 separate pastures

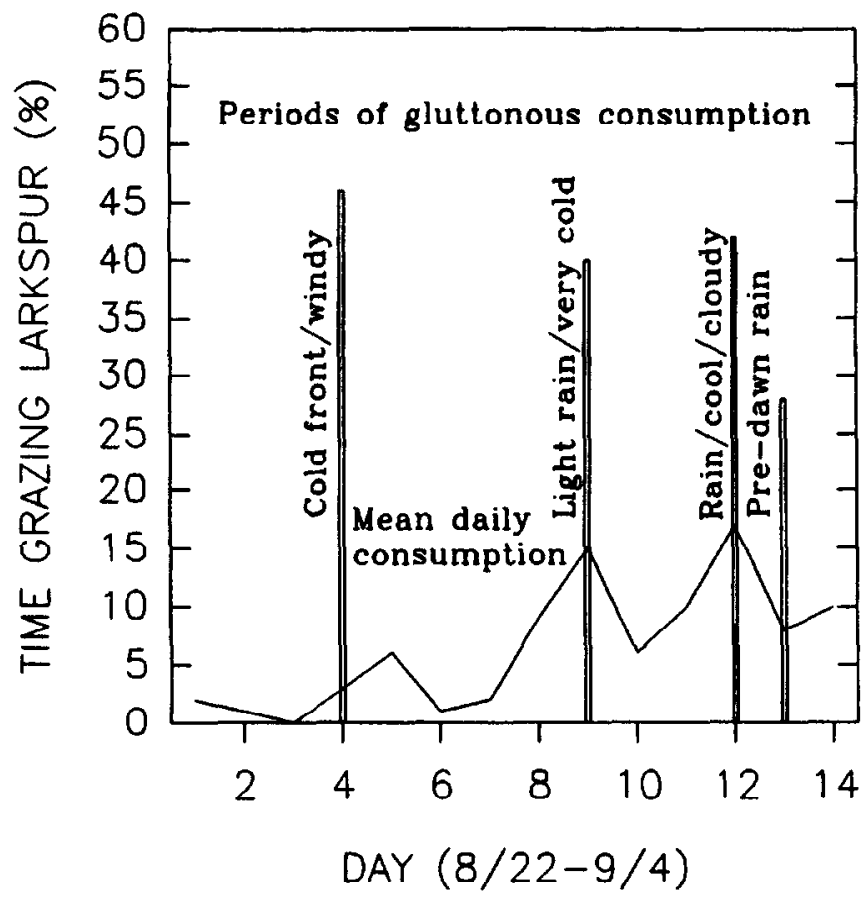

Fig. 1. Mean daily larkspur consumption ( $\%$ of grazing time), periods of gluttonous larkspur consumption, and corresponding weather events during the 1990 grazing study.

and only the control group exhibited gluttonous larkspur consumption. One heifer started eating larkspur pods; 2 others appeared to observe and followed suit. Later, the fourth heifer joined in. They consumed larkspur pods exclusively for about 20 minutes, then went back to eating grass and other forbs.

A mid-afternoon thunderstorm occurred on 29 August when all 12

Table 1. Weather components and their correlation with the proportion of time cattle grazed larkspur.

\begin{tabular}{|c|c|c|c|c|c|}
\hline & & \multicolumn{2}{|c|}{ Grazing periods ${ }^{1 /}$} & \multicolumn{2}{|c|}{ Mean for day ${ }^{2}$} \\
\hline & & $r$ & $P$ & $r$ & $P$ \\
\hline Relative Humidity & $\%$ & 0.27 & 0.01 & 0.45 & 0.01 \\
\hline $\begin{array}{l}\text { Precipitation } \\
2 \text { hour accumulation } \\
24 \text { hour accumulation }\end{array}$ & $\mathrm{cm}$ & 0.04 & 0.86 & 0.27 & 0.16 \\
\hline Leaf wetness & $\%$ of time & 0.55 & 0.003 & 0.74 & 0.006 \\
\hline $\begin{array}{l}\text { Wind speed } \\
\text { Wind gust }\end{array}$ & $\mathrm{m} / \mathrm{sec}$ & $\begin{array}{l}0.05 \\
0.11\end{array}$ & $\begin{array}{l}0.78 \\
0.58\end{array}$ & $\begin{array}{l}-0.16 \\
-0.15\end{array}$ & $\begin{array}{l}0.60 \\
0.64\end{array}$ \\
\hline Temperature & $\mathrm{C}$ & -0.38 & 0.0009 & -0.52 & 0.004 \\
\hline $\begin{array}{l}\text { Barometric pressure } \\
3 \text { hour change in } \\
\text { pressure }\end{array}$ & mm mercury & $\begin{array}{l}-0.36 \\
-0.04\end{array}$ & $\begin{array}{l}0.001 \\
0.86\end{array}$ & -0.60 & 0.0007 \\
\hline Solar radiation & watts $/ \mathrm{m}^{2}$ & -0.21 & 0.31 & -0.34 & 0.27 \\
\hline
\end{tabular}

'Correlation hetween larkspur consumption and the respective weather component during three major grazing periods each day.

${ }^{2}$ Correlation between the mean daily larkspur consumption and the average daytime value of the respective weather components. 

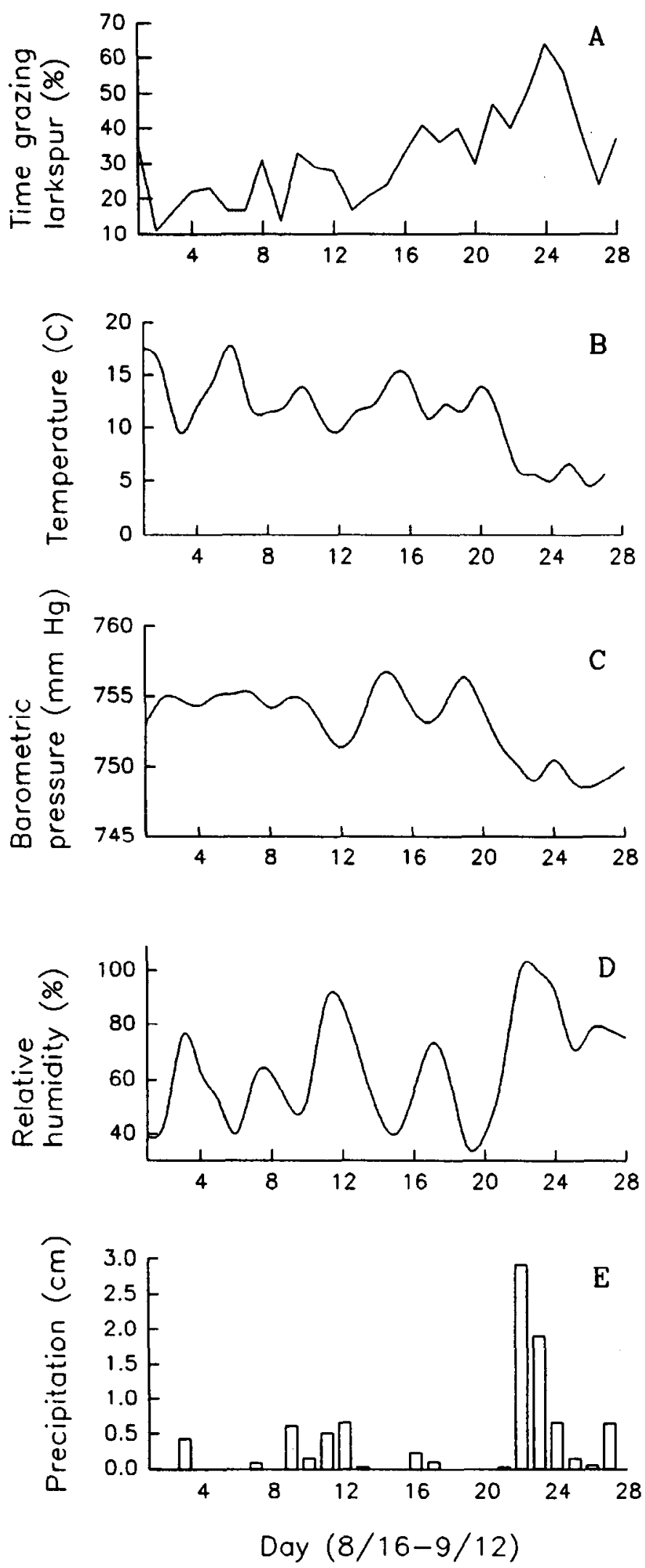

Fig. 2. a) Mean daily larkspur consumption by cattle ( $\%$ of grazing time) during the 1991 grazing study, b) mean daily barometric pressure ( $\mathrm{mm}$ mercury), c) average daytime temperature (C), d) mean relative humidity $(\%)$, e) and daily precipitation $(\mathrm{cm})$. heifers were grazing together. Following the storm, while it was still misty, 3 heifers began consuming larkspur. Four others observed, then also joined in. A few minutes later, 2 more started, and by the end of $30 \mathrm{~min}$, all but 1 heifer was eating larkspur.

A heavy thunderstorm occurred during the afternoon of 1 September. It was cold and cloudy during the evening grazing period and all heifers consumed large quantities of larkspur. The following day, 1 heifer showed initial signs of larkspur poisoning and she left the group and laid down in a grove of trees for the entire day. However, she resumed normal feeding the next day.

The morning of 2 September was cold and cloudy and a heavy dew remained on the plants from the previous nights rain. All 12 heifers consumed large amounts of larkspur during this period and ate it exclusively for a 5 -min period.

\section{Correlation of Diets with Weather Components}

Larkspur consumption ranged from 10 to $60 \%$ of grazing time in the 1991 grazing study (Fig. 2a). Correlations between larkspur consumption and the mean daytime values of the weather components were higher than for correlations with weather components during individual grazing periods during the day (Table 1). Mean daily larkspur consumption was negatively correlated with the average day time temperature and barometric pressure $(r=-0.52$ and -0.60 respectively), and positively correlated with relative humidity, leaf wetness, and 24 hour precipitation ( $r=0.45,0.74$ and 0.27 , respectively). Temperature (Fig. 2b) and barometric pressure (Fig. 2c) declined during stormy periods, while relative humidity (Fig. 2d) and precipitation (Fig. 2e) increased.

\section{Discussion}

Results from these 2 studies, and observations from other grazing studies (Pfister et al. $1988 \mathrm{ab}$, Lane et al. 1990, Ralphs and Olsen $1992 \mathrm{ab}$ ) suggest that cattle increase larkspur consumption during or following storms. This accounts for the reported increase in cattle deaths following storms (Wilcox 1899, Glover 1906, Marsh and Clawson 1916).

The toxic dose of larkspur is determined by the level of the toxic alkaloid methyllycoconitine (MLA) in the larkspur plant and the rate at which cows consume the plant. Weather may affect both animal and plant factors associated with poisoning.

The literature suggests weather can alter livestock grazing behavior by influencing the length and time of feeding periods. Cattle increase feed intake in feedlots as barometric pressure falls preceding storms (L.F. James, personal observation). Livestock reduce grazing time in response to extreme heat or cold (Arnold and Dudzinski 1978). Cattle are more restless, graze less intensely, and travel more in cloudy or stormy weather (Culley 1938). Weather variables associated with storms (temperature, relative humidity, and barometric pressure) decreased feed intake by sheep and accounted for 2 to $20 \%$ of variability in intake (Wohlt et al. 1988). Each storm develops its own special shifts in wind direction and velocity. It is preceded and followed by an individualized pattern of changes in barometric pressure, temperature, and humidity. Atmospheric electricity is associated with some. but not all storms. The composition of the air itself may change, becoming either more or less ionized as the storm passes which may influence disposition or mood changes (Richardson et al. 1968, Rosenberg et al. 1983, Tromp 1980). All of these factors, their intensity, and order in which they change, affect the degree of an individual animal's reaction to a storm.

Weather has a major influence on the internal chemistry and toxicity of plants. Frost increases hydrogen cyanide levels in arrowgrass, 
chokecherry, and sorghum, and tannin content in oak leaves (Kingsbury 1964). Several plant species increase toxin levels following rain, due to increased metabolic activity: nitro toxins increase in columbia milkvetch following rains (Majak et al. 1976), and grass tetany occurs during cool, stormy weather due to the imbalance of magnesium in cool season grasses (Robinson et al. 1989). On the other hand, cloud cover reduced quinolizidine alkaloid levels in Lupinus albus L. in the diumal cycle of alkaloid synthesis (Wink and Witte 1984). Alkaloids in other plants increase during periods of cool cloudy weather and during mild water stress, when photosynthesis decreases and nutrients are shunted to defense chemicals (Bryant et al. 1983, Gershenzon 1984). Larkpsur alkaloid levels vary tremdously (Manners et al. 1993). The toxic alkaloid MLA is highest in early growth, declines as the plant matures, but increases slightly in the pods (Pfister et al. 1994). Larkspur consumption by both cattle and sheep increases as the plant matures, suggesting a negative relationship between alkaloid levels and palatability (Ralphs et al. 1988). We are currently conducting research to determine how toxic alkaloid levels respond to stormy weather.

Based on the results from this study, our observations, and the literature, we hypothesize that weather components affect the internal chemistry of the larkspur plant making it more palatable. The weather components may reduce the level of total alkaloids, making the plant les objectionable. The chilling effect may alter carbohydrate metabolism and increase the sugar levels in the leaves, thus making the plant more palatable. They may alter some chemical that makes the plant attractive. Or the combination of alkaloids may combine for a unique taste which the cattle are seeking (see Molyneux and Ralphs 1992). The rain may also wash off the bitter-tasking wax that builds up on the leaves. These plant factors can be evaluated chemically and tested for their influence on palatability in controlled feeding and grazing trials.

\section{Literature Cited}

Arnold, G.W. and M.L. Dudzinski. 1978. Ethology of free-ranging domestic animals. Elsevier, New York.

Bryant, J.P., F.S. Chapin III and D.R. Klein. 1983. Carbon/nutrient balance of boreal plants in relation to vertebrate herbivory. Oikos 70:357-368.

Cronin, E.H, and D.B. Nielsen. 1979. The Ecology and Control of Rangeland Larkspurs. Utah Agr. Exp. Sta. Bull. 499. p. 34.

Culley, M. J. 1938. Grazing habits of range cattle. J. For. 36:715-717.

Gershenzon, J. 1984. Changes in the levels of plant secondary metabolites under water and nutrient stress. pp 273-320 in B.N. Timmermann, C. Steelink and F.A. Loewus (eds), Recent Advances in Phytochemistry: Phytochemical Adaptations to Stress. Plenum Press, New York.

Glover, G.H. 1906. Larkspur and other poisonous plants. Colo. Agr. Exp. Sta. Bull.:113.
Kingsbury, J.M. 1964. Poisonous Plants of the United States and Canada. Prentice Hall Inc., Englewood Cliffs NJ. pp. 131-140.

Lane, M.A., M.H. Ralphs, J.D. Olsen, F.D. Provenza, and J.A. Pfister. 1990. Conditioned taste aversion: potential for reducing cattle loss to larkspur. J.Range Manage. 43:127-131.

Lehner, P.N. 1987. Design and execution of animal behavior research: an overview. J. Anim. Sci. 65:1213-1219.

Majak, W., R.J. Williams, A.L. Van Ryswyk, and B M. Brooke. 1976. The effect of rainfall on Columbia milkvetch toxicity. J. Range Manage. 29:281-283.

Manners, G.D., K.E. Panter,M.H. Ralphs, J.D. Olsen and L.F. James. 1993. Toxicity and chemical phenology and norditerpenoid alkaloids in the tall larkspur (Delphinium species). J. Agric. Food Chem. 41:96-100.

Marsh, C.D., and A.B. Clawson. 1916. Larkspur poisoning of livestock. USDA Bull. 365.

Molyneux, R.J. and M.H. Ralphs. 1992. Plant toxins and palatability to herbivores. J. Range Manage. 45:13-18.

Pfister, J.A., G.D. Manners, M.H. Ralphs, Z.X. Hong, and M.A. Lane. 1988a. Effects of phenology, site and rumen fill on tall larkspur consumption by cattle. J. Range Manage. 41:509-514.

Pfister, J.A., M.H. Ralphs, and G.D. Manners. 1988b. Cattle grazing tall larkspur on Utah mountain rangeland. J. Range Manage. 41:118-122.

Pfister, J.A., G.D. Manners, D.R. Gardner and M.H. Ralphs. 1994. Toxic alkaloid levels in tall larkspur (Delphinium barbeyi) in Colorado. J. Range Manage. (in press).

Ralphs, M.H., J.D. Olsen, J.A. Pfister and G.D. Manners. 1988. Plant-animal interactions in larkspur poisoning in cattle. J. Anim. Sci. 66:23342342.

Ralphs, M.H., and J.D. Olsen. 1992a. Prior grazing by sheep reduces waxy larkspur consumption by cattle: an observation. J. Range Manage. 45:136139.

Ralphs, M.H., and J.D. Olsen. 1992b. Comparison of larkspur alkaloid extract and lithium chloride in maintaining cattle aversions to larkspur in the field. J. Anim. Sci. 70:1116-1120.

Richardson, E.A., L.M. Cox, and G.L. Ashcroft. 1968. Bioclimatology - a practical science... man/nature's recalcitrant anomaly. Utah Sci. 29:13371341.

Robinson, L.L., L.C. Kappel, and J.A. Boling. 1989. Management practices to overcome the incidence of grass tetany. J. Anim. Sci. 67:34703484.

Rosenberg, N.J., B.L. Blad, and S.B Verma. 1983. Microclimate, the Biological Environment. 2nd Ed. John Wiley \& Sons, New York.

SAS. 1985. Sas Procedures Guide for Personal Computers. 6 Ed. SAS Institute Inc. Cary NC.

Tromp, S.W. 1980. Biometerology - The Impact of the Weather and Climate on Humans and their Environment (Animals and Plants). Heyden, London.

Wilcox, E.V. 1899. Cattle poisoning by the tall larkspur. Mont. Agr. Exp. Sta. Bull. 22.

Wink, M. and L. Witte. 1984. Tumover and transport of quinolizidine alkaloids. Diurnal fluctuations of lupaine in the phloem sap, leaves and fruit of Lupinus albus L. Planta 161:519-524.

Wohit, J.E., L.G. James, and J.R. Trout. 1988. Influence and necessity of defining temperature, relative humidity and barometric pressure when conducting feed intake studies. Nutrition Reports Internat. 37:357-362. 